\title{
The Impact of Audit Committe Characteristics on Audit Quality
}

\author{
Paradisa Sukma and Yustrida Bernawati \\ Faculty of Economic and Business, University of Airlangga, Surabaya \\ Email: sukmaparadisa@gmail.com and yustridabernawati@yahoo.com
}

\begin{abstract}
This research was conducted to investigate the effect of audit committee characteristics on audit quality. The characteristics of the audit committee used in this study are the number of audit committees, number of audit committee meetings, audit committee education background, and audit committee experience while audit quality is measured using audit fees. This study uses manufacturing companies listed on the Indonesia Stock Exchange in 2016 - 2018 with 70 observation data and uses OLS regression. The results of this study indicate all four Audit Characteristics, only size and experience significantly influence audit quality. While audit meetings and education do not significantly affect audit quality. Likewise with the education that can not ensure the capabilities possessed by members of the audit committee. Overall, the effectiveness of the audit committee has no significant effect on audit quality.
\end{abstract}

Keywords: Audit Quality, Audit Fees, Audit Committee.

\section{INTRODUCTION}

Audit quality is a guarantee given by the auditor of high-quality financial reporting which is a function of the company's financial reporting system and its inherent characteristics (DeFond and Zhang, 2014). Based on the Public Accountant Professional Standards (SPAP), the audit results are said to have good quality if they meet the provisions of the auditing standard including the professional quality of independent auditors used in conducting audits and preparing auditor reports. Good audit quality is expected to produce a quality company financial report, in which financial statements are needed by various parties, including investors and creditors in the context of decision making (DeAngelo, 1981). To get decisions that suit the needs of investors and creditors, good quality of audited financial statements are needed. So the increase in quality of audits become urgent because with high audit quality it will produce high-quality financial reporting (DeFond and Zhang, 2014). This shows that audit quality is important and urgent for a company.

In practice, audit quality in Indonesia is still questionable. This is due to the many cases of manipulation of financial statements that occur. Also, there is the involvement of public accountants in the case of manipulation. One of them is PT Garuda Indonesia Tbk which is proven to report fictitious income figures on the 2018 Financial Statements as well as the Kasner Sirumapea Public Account (PA) and the Public Accounting Firm Tanubrata, Sutanto, Fahmi, Bambang \& Partners as auditors who audit financial statements Garuda Indonesia conducts audit procedures that are not following accounting standards. Besides Garuda Indonesia, another manipulation case occurred at PT Indosat 
Tbk, where the auditor modified the working papers and was not cooperative in examining the company's financial statements. The same case also happened to PT SNP Finance, which reported fictitious financial statements, namely hiding its debts to facilitate credit applications and obtain reasonable opinions without exception from independent auditors who examined their financial statements. In addition, during November 2018 - June 2019 there were eleven Public Accountants (PA) who were imposed sanctions namely PA Abdulrahman Hasan Salipu, PA Indra Soesetiawan, PA Hussen Shahab, PA Anwar, PA Armandias, PA Heri Mardani, PA James Pardomuan Sitorus, PA I Gede Auditta PP, PA Kasner Sirumapea, PA Purboyo Adhi Purnomo, and PA Sugeng Wirjaseputra. Eleven PAs have suspended for a while because they have violated regulations related to the profession of Public Accountans. Sanctions are given by the Ministry of Finance in the form of license suspension in receiving public accountant services, such as audit services on financial reports, review services, and other insurance services. This freezing is carried out for 6 (six) months to 15 (fifteen) months.

Actions to improve audit quality are very important, because low audit quality will increase the likelihood of opinions on improper financial statements (Elinda et al., 2019). The low quality of audits in Indonesia can occur due to several factors that influence it. One of them is the audit committee which is part of corporate governance which has the duty and authority in improving the integrity of financial reporting will have an impact on improving audit quality. Based on POJK-55 concerning the Establishment and Guidelines for the Implementation of the Audit Committee's Work (2015), one of the roles of the audit committee is to examine the financial information that will be issued by the Issuer or Public Company to the public and the authorities including financial reports, projections, and other reports related to financial information. Based on this role the audit committee in the corporate governance mechanism is expected to improve audit quality through the role of supervision of the reliability of the company's financial statements and the effectiveness of internal control over the financial statements. (Mustafa et al., 2018) explain that audit committees can increase client incentives to employ strong external monitoring mechanisms. (Sofia and Avianti, 2019) said that the audit committee characteristics affect the quality of audits produced by public accountants positively through internal oversight activities carried out by the audit committee. The theoretical basis for the audit committee is the agency theory in which an properly constructed audit committee is expected to improve the quality of governance, specifically by improving the quality of financial reporting and auditing (Cohen et al., 2004; Mustafa et al., 2018; Turley and Zaman, 2007).

Several previous studies have tried to look at the characteristics of the audit committee in influencing audit quality. Audit committee and audit quality are a unit so that if the audit committee is an effective company, it will achieve good audit quality (Ali et al., 2018; (Asiriuwa et al., 2018); (Mustafa et al., 2018). (Ali et al., 2018) examined the relationship between audit committees and audit quality through a combined index of audit committee effectiveness, namely: independence, financial expertise, accounting expertise, meetings, and size. The results of the study are that the effectiveness of the audit committee has a significant effect on audit quality, which means an increase in the effectiveness of the audit committee leads to better audit quality. The research findings also indicate that the five attributes have a significant influence in increasing the effectiveness of the audit committee. (Mustafa et al., 2018) examined the characteristics of the audit committee, such as size, independence, and meetings in influencing audit quality. 
The results in the study indicate that the size and independence of the audit committee increase the company's incentives to employ strong external monitoring mechanisms. But often audit committee meetings actually hamper the quality of the audit. (Kusnadi et al., 2016) examined the independence and characteristics of the audit committee in influencing the quality of corporate financial reporting. The results of this study indicate that the independence of the audit committee does not have a significant impact on the quality of a company's financial reporting. However, accounting expertise and the mixed expertise of the audit committee have a significant impact on the quality of financial reporting where the presence of these skills will provide better monitoring of the financial reporting process.

(Al-Hajaya, 2019) examined the effect of audit committee effectiveness as a corporate governance tool on audit quality in Jordan and showed the results that audit committee effectiveness affected audit quality. Similar results were obtained by (Asiriuwa et al., 2018); (Inaam and Khamoussi, 2016). However, (Zaman et al., 2011) found no relationship between the two in their research conducted in England. Likewise with the findings produced by (Goodwin-Stewart and Kent, 2006; Rainsbury et al., 2009).

This research was conducted to investigate the effect of audit committee characteristics that are part of the corporate governance mechanism on audit quality through the provision of incentives (audit fees) to independent parties or public accounting firms. This research will contribute theoretically to future researchers to become a reference in developing research in the field of auditing and corporate governance. In addition, this research can strengthen previous studies relating to the audit committee and audit quality. While practically, this research can be a reference in considering the right composition to form a reliable audit committee in the company.

The results of this study show that of the four characteristics used, namely size, number of meetings, educational background and experience of the audit committee, only two had a significant influence, namely the size of the audit committee and the experience of the audit committee. The size of the audit committee affects the cost of the audit with an increasingly large amount, it will get wider considerations so as to increase audit costs to get better audit quality. Whereas experience in accounting and finance owned by the audit committee will reduce audit costs because audit committee members who have experience in accounting and finance can conduct more stringent supervision when preparing financial statements before being audited. A higher quality of financial statement input for auditing will result in lower audit fee decisions.

Two other characteristics such as the number of meetings and educational background do not affect audit quality. The high number of meetings conducted by the audit committee did not have a significant effect because each meeting did not always focus on discussing audit fees. Likewise with an educational background that does not necessarily indicate the ability of members of the audit committee, so that no significant effect in making audit fees decisions. Based on these four characteristics, the effectiveness of the audit committee in the company does not significantly influence the audit costs because the companies used in this study have the majority of high effectiveness scores or are considered effective so that they do not influence significantly.

The implication of this research for practitioners is as a reference in determining the right composition to have an audit committee that can carry out its functions optimally. As 
for regulators, this research can be used as a basis for strengthening the qualifications needed by an audit committee to carry out its duties and authority properly.

\section{THEORETICAL REVIEW}

Agency Theory. Agency theory put forward by (Jensen and Meckling, 1976) who discusses the working relationship between the principal, namely the party giving authority and the agent, the party receiving authority. (Scott, 2015) defines agency theory as a branch of game theory that studies a contract design to motivate agents to act on behalf of the principal when the agent's interests conflict with the principal's interests. Principals employ agents to carry out tasks in the interests of principals, including delegation of authorization for decision-making from principals to agents. In companies whose capital consists of shares, shareholders act as principals and managers as their agents. Shareholders employ managers to act in accordance with the interests of the principal. But in reality, company managers often have different goals and may conflict with the main objectives between the shareholders. Problems arising from conflicts of interest between managers and shareholders are called agency problems. This conflict can then trigger agency fees. (Jensen and Meckling, 1976) define agency fees in three types. First, monitoring costs are the costs incurred to supervise the activities carried out by the agent. Second, bonding costs are costs to ensure that the agent will not act against the principal, or in other words to convince the agent, that the principal will compensate if the agent actually does the action. Third, the residual cost is the value of money equivalent to the reduction in prosperity experienced by the principal due to the divergence of interest.

The implication of agency theory in this study is that the audit committee which is part of corporate governance has a supervisory function in ensuring that the financial statements issued by the company show the actual condition of the company. In addition, the audit committee has the authority to determine the incentives given to audit service providers to produce high audit quality. But on the other hand, the audit committee is part of a company that has an interest in showing the good and healthy condition of the company to users of financial statements. So this study looks at how the characteristics of the audit committee at the company improve audit quality through the provision of these incentives.

Audit Committee. The concept of the audit committee was originally recommended by the American Institute of Certified Public Accountants (AICPA) in 1967 that the establishment of an audit committee board to assist the reporting process. the audit committee is part of the corporate governance mechanism by which Good Corporate Governance is implemented so that the company can achieve its objectives (Bandiyono, 2019). (Enofe et al., 2013); (Li et al., 2012) explained that the audit committee can be described as a corporate governance mechanism burdened with responsibility for ensuring quality reporting by performing the supervisory function of management activities and external auditors. In addition, the audit committee also helps reduce agency problems between management and the owner. Thus, the presence of the audit committee must produce quality and independent reporting. The Sarbanes Oxley Act (2002) defines it as a committee formed by a board of directors to oversee the processes involved in the accounting and financial auditing of companies. According to (Li et al., 2012) the audit 
committee can be used as an effective tool to ensure the quality reporting process. (Putra and Ratnadi, 2018) explains that the establishment of an audit committee within the company is carried out with the aim to help the performance of the board of commissioners in carrying out the supervisory function of the company. However, if this must be achieved, the audit committee must have several characteristics such as independence, frequent meetings, and financial experts.

Regulations related to audit committees in Indonesia are slightly different from other countries. In Indonesia, the Audit Committee is one of the committees formed to assist commissioners in carrying out their duties. According to POJK Number 55/POJK.04/2015, the Audit Committee is a committee formed by and responsible to the Board of Commissioners in helping carry out the duties and functions of the Board of Commissioners. In carrying out its functions, the Audit Committee has duties and responsibilities including reviewing financial information to be issued by Issuers or Public Companies to the public and recommending to the Board of Commissioners regarding the appointment of an Accountant based on independence, the scope of the assignment, and service fees.

The composition of the Audit Committee must be prepared so that it can accommodate the complexity of the company by considering its effectiveness in decision making. POJK Number 55 / POJK.04 / 2015 stipulates that the number of audit committee members in the company consists of a minimum of three members, chaired by an independent commissioner. While other members are independent external parties with at least one of them having the ability in accounting and or finance. in addition, the AIDS committee must hold regular meetings at least every three months. With this competency, it is expected that the audit committee can do its job to review all important matters of the company's financial reporting (Putra and Ratnadi, 2018). For public companies, stateowned companies, provincial and regional-owned companies, companies that collect and manage public funds, companies whose products or services are widely used by the public and companies with extensive influence on the environment. The Audit Committee is chaired by an Independent Commissioner and members can consist of Commissioners and or professionals from outside the company. One member must have an accounting and/or financial background.

Audit Quality. Audit quality is a process carried out by auditors to ensure client companies follow applicable auditing standards, following special quality control procedures helps to consistently meet the standards in their assignments until good quality results are achieved (Arens et al., 2016). In achieving good audit quality, it must be included by following established standards, namely general standards, fieldwork standards, and reporting standards.

Some studies define audit quality with a variety of variations. (DeAngelo, 1981) says that audit quality is the possibility that auditors can detect violations in the client's accounting system and report these violations. But according to (DeFond and Zhang, 2014) the role of auditors is more than simple detection related to reporting. High-quality auditors are expected to consider not only whether the client's accounting choices are in accordance with technical rules, but also how well the financial statements reflect the company's actual economy. The role of the auditor in ensuring the quality of financial reporting is also consistent with audit opinions, which provide assurance that the financial 
statements are fairly presented in accordance with applicable regulations. This shows that the auditor paid attention to how the rules were applied and how the consistency between the report and the actual conditions.

(DeFond and Zhang, 2014) argue that audit quality can be concluded by considering audit input through the Auditor-client contracting features. Information about audit quality can also be deduced from auditor-client contract features, such as audit fees. Audit costs are used to represent audit quality because they are expected to measure the level of auditor effort, which is an input to the audit process that is intuitively related to audit quality. The distinguishing feature of audit fees is that they are the result of both supply and demand factors. The auditor cannot unilaterally charge a higher fee for additional efforts unless there is an increase in client demand for additional efforts. As a result, audit fees are used in demand and supply studies. For example, in-demand studies, audit fees are often used to test whether audit committee competencies are associated with audit quality. In supply studies, audit costs are most often used to test whether audit quality is associated with litigation risk and whether Big $\mathrm{N}$ auditors or industries are related to audit quality Audit costs have several advantages in measuring audit quality. The advantage is that they are continuous so that they catch subtle variations in quality. Another advantage is that the literature has developed a relatively sophisticated cost model with $\mathrm{R}$-squared often exceeding $70 \%$, which to some extent reduces concerns about correlated omitted variables.

Audit costs also have weaknesses that limit the interpretation of their results. One of them is that in addition to capturing audit efforts, costs also capture risk premiums (funds released for decision making) and increase audit efficiency. This is a critical limitation because it means that an increase in audit costs cannot be interpreted clearly as an increase in audit quality. A further limitation is that costs capture the shared results of supply and demand factors. As such, researchers must be careful in interpreting the results from cost studies.

\section{HYPOTHESIS}

Financial Services Authority Regulation Number 55/POJK.04/2015 concerning the Formation and Guidelines for Work Implementation of the Audit Committee explains that one of the tasks of the audit committee is to review financial information that will be issued by the Issuer or Public Company to the public and/or authorities, including financial statements, projections, and other reports related to financial information of Issuers or Public Companies. This shows that the audit committee has a stake in ensuring the quality of financial statements that the company will issue to external users. In addition, the audit committee also has the task to determine the amount of incentives provided to the audit service provider.

Based on the Financial Services Authority Regulation No. 55/POJK.04/2015, the number of people who must be on the audit committee of each company has been determined. Specifically, the regulation stipulates that the audit committee must total at least four and must be chaired by an independent commissioner. This number is regulated by various considerations so that the audit committee can function properly and can carry out its duties properly. Some studies such as (Mustafa et al., 2018) have examined the relationship between audit committee size and audit quality. The results show that the size of the audit committee can significantly influence the audit committee where the greater the number of audit committees, the higher the audit quality (Asiriuwa et al., 2018; 
Mustafa et al., 2018). This is supported by research by (Bédard and Chtourou, 2004) who argue that large-sized audit committees will have better control and oversight functions that will translate to improve audit quality as a result of having more work. Based on this, the hypothesis proposed:

H1: The size of the audit committee affects audit quality.

Based on the Financial Services Authority Regulation No. 55/POJK.04/2015 which explains that the Audit Committee is expected to meet regularly at least once every three months. This is done to increase the effectiveness in carrying out monitoring functions. The more meetings conducted, the more time can be used by the audit committee to discuss and make decisions. Several previous studies have examined the effect of meetings on audit quality. (Salawu et al., 2017) found a positive and insignificant relationship between audit committee meetings and audit quality. These results are supported by research from (Asiriuwa et al., 2018) which shows that audit committee meetings do not significantly affect audit quality. Therefore, this study hypothesizes that:

H2: Audit committee meetings affect audit quality.

Based on the Financial Services Authority Regulation No. 55/POJK.04/2015 which explains that there is at least one person on the audit committee who has an accounting and financial education background. This is intended so that the audit committee knows in accordance with the scope of work, duties, and authority so as to be able to provide good performance for the company. With the knowledge possessed, the audit committee can play a role in maintaining audit quality that is owned by the company. Therefore, the hypothesis proposed is:

H3: The educational background of the audit committee influences audit quality.

Audit committee experience refers to previous experience working in a department or institution related to accounting and finance. (Juhmani, 2017) asserts that the availability of accounting and financial experience in the audit committee will improve its efficiency and ability to detect and prevent earnings management. In addition to the experience possessed by members of the audit committee, they can take into consideration when executing their duties, especially in determining the incentives to the audit service providers. (Ghafran and O'Sullivan, 2017) explain that audit committee expertise has a positive and significant impact on audit costs which indicates that the audit committee's financial expertise level does indeed improve audit quality. However, (Salawu et al., 2017) also documented an insignificant positive relationship between audit committee expertise and audit quality. Likewise with the same results shown by (Asiriuwa et al., 2018). Thus this study hypothesizes that:

H4: Audit committee experience influences audit quality.

The audit committee as part of the corporate governance mechanism has a duty to review the financial information that will be released by the Company to the public. In addition, the audit committee also has the duty to oversee external audit performance and determine the amount of incentives to be provided. This shows that the audit committee has a stake in producing good audit quality for the company. To fulfill the objectives of the audit committee, an effective audit committee is needed which is seen based on the 
attributes that exist in the audit committee. These attributes based on research conducted by (Ali et al., 2018) are the number of members, number of meetings, expertise, and independence of the audit committee. Previous studies have revealed that audit committee effectiveness has a positive effect on audit quality (Ali et al., 2018; Asiriuwa et al., 2018; Inaam and Khamoussi, 2016). Thus, the proposed hypothesis is:

H5: The effectiveness of the audit committee influences audit quality.

Based on the development of hypotheses, this conceptual development research is:

Figure 1. Conceptual Framework

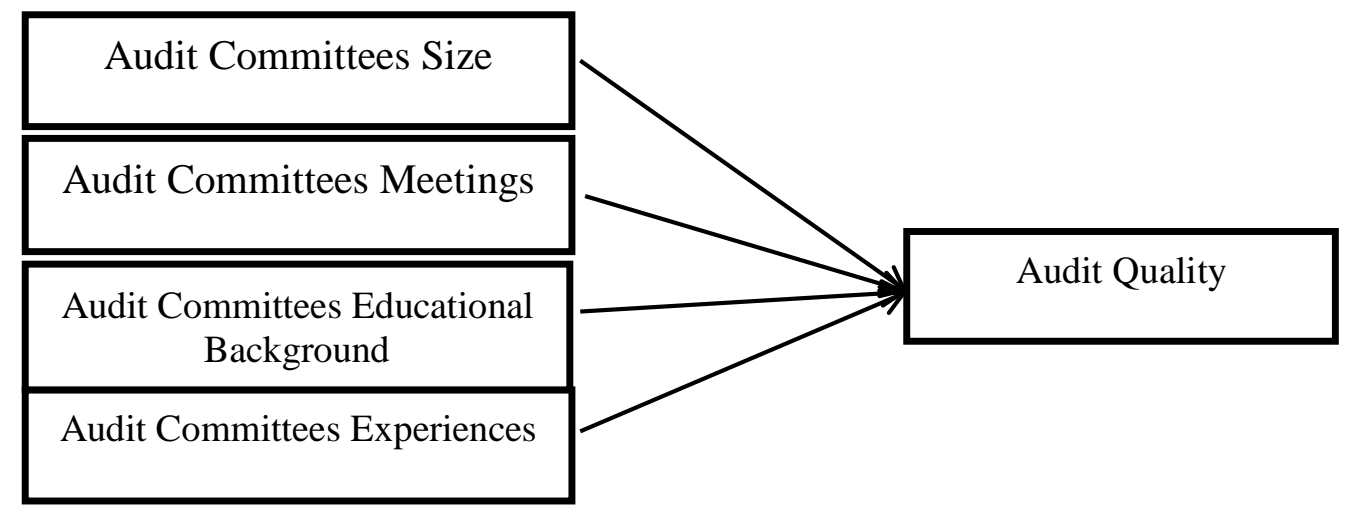

\section{METHODOLOGY}

This study uses a quantitative method with an archival approach that uses secondary data in the form of company annual reports obtained through the Indonesia Stock Exchange website and the company's official website. The sample of this research is manufacturing companies listed on the Indonesia Stock Exchange in 2016-2018. This study uses panel data with sample selection techniques using purposive sampling. The determination of the sample is done using the purposive sampling method, which is the selection of samples based on certain criteria predetermined. The criteria for determining the sample used in this study are companies that provide data related to audit fees and supporting data to see the characteristics of the audit committee in the company's annual report. Based on these criteria, the data obtained were 21 companies for 2016, 25 companies for 2017 and 24 companies for 2018. So that the total data used in this study were 70 observational data. The list of companies used in the study can be seen in appendix 1.

The data collection method used in this study is the documentation method. The documentation method is a method of collecting data by recording and studying documents or archives that are relevant to the problem under study. Documentation of this research is done by downloading and viewing data from annual reports of publicly available companies available on the IDX website and company website. The analytical tool used to test the hypothesis in this study is multiple linear regression (OLS Regression) with testing using IBM SPSS ver 25. 


\section{Operational Definition and Variable Measurement}

Audit Quality. Audit quality according to (DeAngelo, 1981) is a probability where an auditor is able to detect and report violations that exist in his client's accounting system. Audit quality is proxied through an input base of Auditor-client contracting features. Information about audit quality can also be deduced from auditor-client contract features, such as audit fees. Audit costs are used to represent audit quality because they are expected to measure the level of auditor effort, which is an input to the audit process that is intuitively related to audit quality. Audit costs are measured using the natural logarithm of audit fees (Ln Audit Fees). The higher audit costs incurred by the companies are indicated as the higher quality audit that will be provided by public accounting firms.

Characteristics of the Audit Committee. The audit committee on audit costs can be examined from two demand and supply perspectives (Goodwin-Stewart and Kent, 2006). The reason from the demand perspective is that the existence of an audit committee within the company will endeavor to improve audit quality. Because of the audit committee functions as a corporate governance mechanism that deals with issues surrounding the integrity of financial reporting, the audit committee can request more audits to be carried out, in terms of scope and effort and a higher level of assurance - looking so that financial reporting produces audit quality better and credibility. This request causes the audit fee to increase. Characteristics of audit fees used in this study are: (1) Number of Audit Committees. The number of audit committees is the number of audit committee members owned by a company. (Al-Musali et al., 2019) suggest that the control and monitoring function will increase with a larger number of audit committees because the broader view and expertise offered by the larger committee will enable audit committees to perform their monitoring roles better. The number of audit committees is measured by the number of audit committee members in the company. (2) Number of audit committee meetings. The number of audit committee meetings is the number of meetings conducted by members of the audit committee each year. According to (Al-Musali et al., 2019) the audit committee must be active in order for its tasks and objectives to be achieved. The activity of the audit committee is carried out by holding meetings. The number of audit committee meetings is measured by the number of meetings conducted by the audit committee incorporated in the company organization per year. (3) Audit Committee Educational Background. Audit committee education is the educational background held by the audit committee in finance and accounting. The educational background on the improving audit committee will improve the performance of the audit committee because it is supported with appropriate capabilities. Audit committee education is measured by the number of audit committees with accounting and financial backgrounds per year. (4) Audit committee experience. Audit committee experience is the expertise and experience possessed by the audit committee in finance and accounting. (Al-Musali et al., 2019) said that the need for members of the subcommittee to become financial and accounting experts on the grounds that knowledge of accounting concepts and the audit process would increase their understanding of financial reporting process. The audit committee's experience is measured by the number of audit committees that have accounting and financial experience. A person is said to have accounting experience if he has experience as Vice President of Finance, CFO, controller, accounting officer, or as CPA (SEC, 2003). Whereas someone is said to have financial experience if he has experience in investment 
banking, loan/credit rating experience, or financial analyst experience (SEC, 2003). (5) Effectiveness of the Audit Committee. The effectiveness of the audit committee is measured using a composite audit committee score in accordance with research conducted by (Ali et al., 2018) based on four attributes, namely: number of members, number of meetings, education, and audit committee experience. The score is a combined measure that sums the values of the four dichotomous characteristics of the audit committee to make a firm-specific summary measure of the effectiveness of the audit committee. A higher score is an indicator of a higher audit committee effectiveness. The score of each attribute is obtained from the calculation of the median where attributes with a number above the median will be given a score of 1 and if below the median will be given a score of 0 . So that the maximum value of the audit committee effectiveness score is 4 and a minimum of 0 .

Data analysis techniques used in this study were descriptive statistics, testing classic assumptions, coefficient of determination, $\mathrm{F}$ test and t-test. The models in this study are:

$A F=\propto+\beta_{1} A C$ Size $+\beta_{2} A C$ Meet $+\beta_{3} A C E d u c+\beta_{4} A C \operatorname{Exp}+\beta_{5} A C E++\varepsilon$

Where:

AF : Audit Fees

AC Size : Audit Committees Size

AC Meet: Audit committee meetings

AC Educ: Audit Committee Educational Background

AC Exp : Audit committee experience

ACE : Effectiveness of the Audit Committee

$\propto \quad$ : Konstanta

$\beta 1 \beta 2, \beta 3$ : koefisien regresi parsial

\section{THE RESULTS OF STATISTICAL TESTS}

Table 1. Statistic Descriptive

\begin{tabular}{lcrccrr}
\hline \multicolumn{1}{c}{ Variabel } & $\mathbf{n}$ & Mean & Median & Std. Dev & Max & \multicolumn{1}{c}{ Min } \\
\hline AF & 70 & 20,80 & 20,63 & 1,45 & 24,57 & 18,47 \\
AC Size & 70 & 3,04 & 3,00 & 0,36 & 4,00 & 2,00 \\
AC Meet & 70 & 5,87 & 4,00 & 3,86 & 21,00 & 3,00 \\
AC Educ & 70 & 2,36 & 2,00 & 0,66 & 4,00 & 0,00 \\
AC Exp & 70 & 2,27 & 2,00 & 0,78 & 3,00 & 1,00 \\
ACE & 70 & 3,46 & 4,00 & 0,63 & 4,00 & 2,00 \\
\hline
\end{tabular}

(Processed data, 2019)

Table 1 illustrates the characteristics of the variables used in this study. This table shows the average value of an audit fee of 20.80 which is equivalent to $\mathrm{Rp}$ $3,804,735,821.00$. There is a big difference in audit fees ranging from a minimum of 18.47 which is equivalent to Rp 105,000,000.00 issued by PT Betonjaya Manunggal Tbk up to a maximum value of 24.57 which is equivalent to $\mathrm{Rp} 47,000,000,000.00$ issued by PT Astra 
International Tbk. The standard deviation is 1.45 which is smaller than the average value so that the data for audit quality is homogeneous.

The average and median for the size of the Audit Committee (AC Size) are 3.04 and 3.0 which shows that in general, the company has an audit committee of 3 (three) people in accordance with POJK Number 55/POJK.04/2015. The lowest number of audit committees in the company is 2 (two) people, namely PT Kertas Basuki Rachmat Indonesia Tbk. The amount does not comply with regulations related to the minimum number of audit committees in a company. While the highest number of 4 (four) people, namely PT Semen Indonesia Tbk. The average and median for Audit committee meetings is 5.87 and 4.0, which shows that more than half of the companies hold a total of 4 (four) meetings a year in accordance with POJK Number 55/POJK.04/2015. There is a big difference in the number of audit committee meetings where the lowest number of meetings is 3 (three) times and the highest number is 21 (twenty-one) times. The lowest amount is owned by PT Akasha Wira International Tbk and the amount is not in accordance with regulations related to the minimum number of meetings held by the audit committee of a public company. While the highest number is owned by PT PT Semen Indonesia Tbk. The average and median education of the audit committee (AC Educ) is 2.36 and 2.0 implying that the majority of the accounting and financial graduates attending the audit committee are 2 (two) out of 3 (three) members. Likewise with the average and median experience of the audit committee (AC Exp) which is 2.27 and 2.0, which shows that the number of accounting and financial experts present on the audit committee board is 2 (two) out of 3 (three) members. The standard deviation values for the four characteristics are below the mean value which reflects the data for the four characteristics that are homogeneous.

The average effectiveness of the Audit Committee (ACE) is 3.46 which shows that most companies have a score of effectiveness level of 3 (three) to 4 (four). This shows that the audit committee is on average effective.

Table 2. Correlation

\begin{tabular}{lllllrr}
\hline & AF & $\begin{array}{l}\text { AC } \\
\text { Size }\end{array}$ & $\begin{array}{c}\text { AC } \\
\text { Meet }\end{array}$ & $\begin{array}{c}\text { AC } \\
\text { Educ }\end{array}$ & $\begin{array}{l}\text { AC } \\
\text { Exp }\end{array}$ & ACE \\
\hline AF & & $0,515^{* * *}$ & $0,242^{* *}$ & $-0,095$ & $-0,203^{* *}$ & $-0,057$ \\
AC Size & $0,483^{* * *}$ & & $0,476^{* * *}$ & 0,118 & 0,010 & 0,169 \\
AC Meet & $0,391^{* * *}$ & $0,384^{* * *}$ & & 0,007 & $-0,287^{* *}$ & $-0,125$ \\
AC Educ & $-0,113$ & 0,092 & $-0,221^{*}$ & & 0,147 & $0,368^{* *}$ \\
AC Exp & -0.180 & $-0,009$ & $-0,111$ & 0,159 & & $0,778^{* *}$ \\
ACE & $-0,104$ & 0,067 & $-0,004$ & $0,300^{* *}$ & $0,802^{* * *}$ & \\
\hline
\end{tabular}

${ }^{\text {a }}$ Pearson Correlation (above) dan Spearman (button).

* The coefficient is significant at the level $10 \%$ (2-tailed test)

${ }^{* * *}$ The coefficient is significant at the level 5\% (2-tailed test)

${ }^{* * *}$ The coefficient is significant at the level $1 \%$ (2-tailed test)

(Processed data, 2019) 
Table 2 shows the correlation coefficients of the variables using Pearson and Spearman. The Pearson correlation matrix outlined in Table 2 shows the size of the audit committee (AC Size) and the audit committee meeting (AC Meet) has a positive and significant relationship at the one percent and five percent levels of audit fees incurred by the company. While the audit committee education (AC Educ), the experience of the audit committee (AC Exp) and the effectiveness of the audit committee (ACE) have a negative relationship with audit fees and are not significant unless the experience is significant at the ten percent level. While the Spearman correlation matrix shows the size of the audit committee (AC Size) and the audit committee meeting (AC Meet) has a positive and significant relationship at the one percent level of audit fees. While the audit committee education (AC Educ), the experience of the audit committee (AC Exp) and the effectiveness of the audit committee (ACE) have a negative relationship with audit fees and are not significant. This shows that the high use of audit committees with graduates and financial accounting experience will reduce audit costs.

Table 3. Estimated Coefficients and p-values of the results of the regression between Audit Quality (Audit Fees) and the characteristics of the audit committee

\begin{tabular}{lcc}
\hline \multicolumn{1}{c}{ Variabel } & Coefficients & p-values \\
\hline AC Size & 0,558 & $0,000^{* * *}$ \\
AC Meet & $-0,099$ & 0,424 \\
AC Educ & 0,170 & 0,137 \\
AC Exp & $-0,337$ & $0,059^{*}$ \\
ACE & 0,161 & 0,381 \\
Adjusted R ${ }^{2}$ & & \\
\hline "The coefficient is significant at the level 10\% (2-tailed test) \\
${ }^{* * *}$ The coefficient is significant at the level 5\% (2-tailed test) \\
${ }^{* * * *}$ The coefficient is significant at the level 1\% (2-tailed test)
\end{tabular}

(Processed data, 2019)

Table 3 presents the results of a series of regressions that seek to ascertain the impact of audit committee characteristics on audit fees. Data processing in this study uses multiple linear regression (OLS Regression). Based on the regression model, adjusted $\mathrm{R}^{2}$ value indicates how much the independent variable used in the study can explain the dependent variable used. In this study, adjusted $\mathrm{R}^{2}$ value is 0,287 which means the independent variable can explain the dependent variable by $28,7 \%$, while $71,3 \%$ can be explained by another variables outside.

The results show that the coefficient value of audit committee size (ACSize) is 0,558 ( $\mathrm{p}$-values $=0,000$ ) which means the size of the audit committee (AC Size) has a positive and significant coefficient at the one percent level which indicates that the size of the audit committee influences audit fees. Thus, hypothesis 1 is supported. These results are consistent with previous studies conducted by Asiriuwa et al. (2018). But different things are shown in the audit committee meeting variable (AC Meet). In table 3, the coefficient value of the audit committee meeting (ACMeet) is $-0,099$ (p-values $=0,424$ ) which explains the audit committee meeting has a negative coefficient and is not significant. This 
shows that the more often the audit committee holds a meeting will not change the decision to provide audit fees by the company insignificantly. This shows that the high number of meetings is not able to improve the quality of the audit because all meetings conducted by the audit committee not necessarily all discuss specifically about the audit fee which means rejecting hypothesis 2 . So that the number of meetings does not have a major impact on audit quality. This result is in accordance with a research by (Asiriuwa $e t$ al., 2018); (Mustafa et al., 2018).

Table 3 shows that the coefficient value of the audit committee educational background (AC Educ) is 0,170 (p-values $=0,137$ ) that means the audit committee educational background (AC Educ) has a positive coefficient and does not significantly indicate that the educational background owned by the audit committee does not affect audit fees. This happens because the educational background does not guarantee that someone has the ability that is suitable for a matter. Because if education is not supported by appropriate experience, education will not have a major impact on audit quality. Therefore hypothesis 3 is rejected. The reverse results are seen in the audit committee experience variable (AC Exp) which has a coefficient value $-0,337$ ( $\mathrm{p}$-values $=0,059$ ). It means the audit committee experience variable (AC Exp) has a negative coefficient and significant at the ten percent level. These results indicate that the experience of working in the accounting and financial department owned by the audit committee significantly influences audit fees so that hypothesis 4 is accepted. the coefficient value of the audit committee effectiveness variable (ACE) in table 3 is 0,161 ( $\mathrm{p}$-values $=0,381$ ) shows positive and not significant coefficients. This means that an effective audit committee can increase audit costs but not significantly. The rejection of this hypothesis 5 can occur because the ACE scores of all companies are not much different, namely the scores that are categorized as effective.

Overall in Table 3 shows that based on four characteristics of the audit committee, only size and educational backgrounds of the audit committee that affect audit quality. The size of the audit committee influences the audit quality in a positive way, whilst the educational background of the audit committee influences the audit quality in a negative way. Whereas audit committee meetings and experiences do not affect audit quality. In addition, table 3 also shows that audit committee effectiveness does not affect audit quality

\section{CONCLUSION}

The purpose of this study is to investigate the effect of audit committee characteristics on audit quality in manufacturing companies in Indonesia. The basis of this research is POJK Number 55/POJK.04/201 which says that the audit committee has the duty to ensure that the financial statements presented by the company show the actual conditions and do not mislead users of the financial statements. In addition, the audit committee also has the authority to determine the audit costs incurred by the company to the public accounting firm. So this study further tests the effect of audit committee characteristics on audit quality as measured using audit fees.

This research uses manufacturing companies in Indonesia for the period of 2016 2018 with 70 observational data. Tests carried out using multiple linear regression and produce that the decision on the determination of audit costs is influenced by the size of 
the audit committee and audit committee experience in accounting and finance. The size of the audit committee affects audit costs because the greater the number of members, it will produce more consideration so that it will tend to increase audit costs to get better audit quality. While the number of audit committee members who have experience in accounting and finance will reduce audit costs because with the experience they have, the audit committee can conduct more stringent supervision when making financial statements before being audited. It is hoped that the quality of financial statement inputs for auditing will be higher and have an impact on lower audit fee decisions. Other characteristics such as the number of meetings, educational background, the effectiveness of the audit committee do not affect audit fees. This is because even though the number of meetings conducted by the audit committee is high but it is not always the focus to discuss audit fees. So it does not have a big effect on audit fees. Likewise with an educational background that does not necessarily indicate the ability of members of the audit committee, so that no significant effect in making audit fees decisions. The audit committee effectiveness variable does not significantly influence the audit costs that can occur because the companies used in this study have the majority of high effectiveness scores or are considered effective so it does not affect significantly.

The limitation of this study is the use of audit committee characteristics that are still too general, such as the total number of meetings in a year, not a meeting that specifically discusses audit fees and how many audit committees come to the meeting. So this can be an opportunity for future research to see specific characteristics to get stronger results. The implication of this research for practitioners is as a reference in determining the right composition to have an audit committee that can carry out its functions optimally. As for regulators, this research can be used as a basis for strengthening the qualifications needed by an audit committee to carry out its duties and authority properly.

\section{REFERENCES}

Al-Hajaya, K. (2019). The Impact of Audit Committee Effectiveness on Audit Quality: Evidence from the Middle East. International Review of Management and Marketing, 9(5), 1.

Al-Musali, M. A., Qeshta, M. H., Al-Attafi, M. A., and Al-Ebel, A. M. (2019). Ownership Structure and Audit Committee Effectiveness: evidence from top GCC capitalized firms. International Journal of Islamic and Middle Eastern Finance and Management.

Ali, M. J., Singh, R. K. S., and Al-Akra, M. (2018). The impact of audit committee effectiveness on audit fees and non-audit service fees: Evidence from Australia. Accounting Research Journal, 31(2), 174-191.

Arens, A. A., Elder, R. J., and Mark, B. (2016). Auditing and assurance services: an integrated approach (16 ed.): Boston: Prentice Hall.

Asiriuwa, O., Aronmwan, E. J., Uwuigbe, U., and Uwuigbe, O. R. (2018). Audit Committee Attributes and Audit Quality: A Benchmark Analysis. Business: Theory and Practice, 19, 37-48.

Bandiyono, A. (2019). The Effect of Good Corporate Governance and Political Connection on Value Firm. Jurnal Akuntansi, Volume XXIII(No. 03 September 2019), 333-348. 
Bédard, J., and Chtourou, S. (2004). The Effect of Audit Committee Expertise, Independence and Activity on Aggressive Earnings Management. Auditing: A Journal of Practice and Theory, 23(2), 13-35.

Cohen, J. R., Krishnamoorthy, G., and Wright, A. (2004). The corporate governance mosaic and financial reporting quality. Journal of accounting literature, 87-152.

DeAngelo, L. E. (1981). Auditor Size and Audit Quality. Journal of accounting and economics, 3(3), 183-199.

DeFond, M., and Zhang, J. (2014). A Review of Archival Auditing Research. Journal of accounting and economics, 58(2-3), 275-326.

Elinda, A. I., Iswati, S., and Setiawan, P. (2019). Analysis of the Influence of Role Stress on Reduced Audit Quality. Jurnal Akuntansi, 23(2), 301-315.

Enofe, A., Aronmwan, E., and Abadua, H. (2013). Audit Committee Report in Corporate Financial Statements: Users' perception in Nigeria. European Journal of Accounting, Auditing and Finance, 1(1), 16-28.

Financial Fervices Authority. (2015). Financial Fervices Authority Regulations Number 55/POJK.04/2015 concerning the Formation and Guidelines for the Work Implementation of the Audit Committee. Jakarta.

Ghafran, C., and O'Sullivan, N. (2017). The Impact of Audit Committee Expertise on Audit Quality: Evidence From UK Audit Fees. The British Accounting Review, 49(6), 578-593.

Goodwin-Stewart, J., and Kent, P. (2006). Relation between external audit fees, audit committee characteristics and internal audit. Accounting \& Finance, 46(3), 387-404.

Inaam, Z., and Khamoussi, H. (2016). Audit Committee Effectiveness, Audit Quality and Earnings Management: A Meta-Analysis. International Journal of Law and Management, 58(2), 179-196.

Jensen, M. C., and Meckling, W. H. (1976). Theory of the Firm: Managerial Behavior, Agency costs and Ownership Structure. Journal of financial economics, 3(4), 305360.

Juhmani, O. (2017). Audit Committee Characteristics and Earnings Management: The Case of Bahrain. International Journal of Accounting and Financial Reporting, 7(1), 11-31.

Kusnadi, Y., Leong, K. S., Suwardy, T., and Wang, J. (2016). Audit Committees and Financial Reporting Quality in Singapore. Journal of Business Ethics, 139(1), 197214.

Li, J., Mangena, M., and Pike, R. (2012). The Effect of Audit Committee Characteristics on Intellectual Capital Disclosure. The British Accounting Review, 44(2), 98-110.

Mustafa, A. S., Che-Ahmad, A., and Chandren, S. (2018). Board Diversity, Audit Committee Characteristics and Audit Quality: The Moderating Role of ControlOwnership Wedge. Business and Economic Horizons (BEH), 14(1232-2019-858), 587-614.

Putra, I. N. W. A., and Ratnadi, N. M. D. (2018). Institutional Ownership, Characteristics of the Audit Committee and Information Power Earnings. Jurnal Akuntansi, 22(3), 405-419.

Rainsbury, E. A., Bradbury, M., and Cahan, S. F. (2009). The Impact of Audit Committee Quality on Financial Reporting Quality and Audit Fees. Journal of Contemporary Accounting \& Economics, 5(1), 20-33. 
Salawu, O., Okpanachi, J., Yahaya, O., and Dikki, C. (2017). Effects of Audit Committee Expertise and Meeting on Audit Quality Of Listed Consumer-Goods Companies in Nigeria. European Journal of Accounting, Auditing and Finance Research, 5(10), 61-79.

Scott, W. R. (2015). Financial Accounting Theory Seventh Edition. United States: Canada Cataloguing.

Sofia, P., and Avianti, I. (2019). Influence of Internal Control Activities And Characteristics Of Audit Committee On The Quality Of Audit Implementation By A Public Accounting Firm. Jurnal Akuntansi, 23(1), 97-112.

Turley, S., and Zaman, M. (2007). Audit Committee Effectiveness: Informal Processes and Behavioural Effects. Accounting, Auditing \& Accountability Journal, 20(5), 765-788.

Zaman, M., Hudaib, M., and Haniffa, R. (2011). Corporate Governance Quality, Audit Fees and Non - Audit Services Fees. Journal of Business Finance \& Accounting, 38(1-2), 165-197. 